\title{
THE ROLE OF U.S. TRADING IN PRICING INTERNATIONALLY CROSS-LISTED STOCKS
}

Joachim Grammig

, University of Tübingen, joachim.grammig@uni-tuegbingen.de

Michael Melvin

Arizona State University, mmelvin@asu.edu

Christian Schlag Goethe-University,SCHLAG@WIWI.UNI-FRANKFURT.DE

Follow this and additional works at: https://fordham.bepress.com/crif_seminar_series

Part of the Finance and Financial Management Commons

\section{Recommended Citation}

Grammig, Joachim; Melvin, Michael; and Schlag, Christian, "THE ROLE OF U.S. TRADING IN PRICING INTERNATIONALLY CROSS-LISTED STOCKS" (2004). CRIF Seminar series. 23.

https://fordham.bepress.com/crif_seminar_series/23 


\title{
THE ROLE OF U.S. TRADING IN PRICING INTERNATIONALLY CROSS-LISTED STOCKS
}

\author{
by
}

Joachim Grammig $^{a}$, Michael Melvin ${ }^{b}$, and Christian Schlag ${ }^{c}$

${ }^{a}$ Faculty of Economics, University of Tübingen, joachim.grammig@ uni-tuegbingen.de, ++49 (7071) 29-

76009

${ }^{\mathrm{b}}$ W.P. Carey School of Business, Arizona State University, mmelvin@asu.edu, (480) 965-6860

${ }^{c}$ School of Business and Economics, Goethe-University, Frankfurt am Main, schlag@wiwi.uni-

frankfurt.de, ++49 (69) 798-22674

This work was stimulated by Andrew Karolyi's discussant remarks on another paper. Helpful comments on an earlier draft were provided by seminar participants at the U.S. Securities and Exchange Commission, the Financial Econometrics session of the Latin American Econometric Society, and the University of Hannover. Advice and assistance in obtaining and interpreting data was provided by Camelback Research Associates, Vicentiu Covrig, Jennifer Juergens, and Paul Labys.

January 2004 


\section{THE ROLE OF U.S. TRADING IN PRICING INTERNATIONALLY CROSS-LISTED STOCKS}

\section{INTRODUCTION}

When a firm's stock is traded simultaneously in both the United States and another country, what should we expect regarding the role of U.S. trading in price discovery? If the evidence indicates that there is a bigger role for U.S. price discovery for some firms than others or for stocks of some countries than others, what determines this different role for different stocks? There is a small literature on the topic of price discovery for internationally cross-listed firms. The evidence regarding where price discovery occurs is mixed. There is some support for an important role for both the home and foreign market and there is also support for the home market dominating price discovery. ${ }^{1}$

The present study is intended to contribute new evidence on this topic.

Specifically, the analysis focuses on the overlap of trading for firms from Canada, France, Germany, and the U.K. with the U.S. Models of the information shares from each market are estimated for the major traded firms. Then a cross-section analysis is employed to identify the important determinants of price discovery across firms. The

\footnotetext{
${ }^{1}$ Studies using high-frequency intradaily data include Ding, Harris, Lau, and McInish (1999) who study Singapore and Malaysia trading and find evidence for price discovery in both markets and Eun and Sabherwal (2003) who study Canada and U.S. trading and also find support for significant price discovery in both markets. Grammig, Melvin, and Schlag (forthcoming) study German and U.S. trading and find support for the home market dominating (that is, German firms have the great majority of price discovery occur in Germany). Studies based upon lower frequency daily data include Kim, Szakmary, and Mathur (2000) who find a small role for U.S. price discovery in the case of firms from Japan, the Netherlands, the U.K., Sweden, and Australia; Lau and Diltz (1994) who find two-way causality between Japanese and U.S. prices of Japanese firms cross-listed in the U.S.; Lieberman, Ben-Zion, and Hauser (1999) who study Israeli firms also traded in the U.S. and find that price discovery occurs in Israel with the exception of Teva, where the U.S. price leads the Israeli price; and Wang, Rui, and Firth (2002) who find that for Hong Kong stocks listed in London, Hong Kong is the dominant market.
} 
time-series evidence on price discovery comes from high-frequency data sampled at 10second intervals. Preliminary analysis indicated that sampling at lower frequencies, as is commonly done in the literature, results in very wide bounds on the information shares of different markets so that the true causality is blurred and one cannot make any strong statements regarding the origins of price discovery. For instance, daily data are simply too highly aggregated to allow strong evidence of causality. In fact, the evidence indicates that sampling even at 10-minute intervals dramatically weakens the causality in the data.

An additional issue related to internationally cross-listed firms is the incorporation of an exchange rate factor. Many studies examine the home and foreign price of stocks by using the exchange rate to convert one price into the same units as the other price. For instance, if French stocks are quoted in euros in Paris and dollars in New York, one could simply convert the Paris price into a dollar equivalent by multiplying the euro price by the dollar/euro exchange rate. Then the analysis may proceed in terms of just the two stock prices, quoted in a common currency. This approach may introduce some problems in inferring price discovery as the effect of exchange rate change is being ascribed to the stock price incorporating the exchange rate. Grammig, Melvin, and Schlag (forthcoming) produce simulation results that show the severe bias that can result from following such an approach. If the goal is to infer price discovery of the two trading locations, then it is important to allow for an independent exchange rate effect. This means that a three variable system should be modeled: the exchange rate, the home market price, and the foreign market price. We follow such a strategy to allow a clear focus on the contribution of each market to price discovery. A by-product of this estimation strategy 
is that we can estimate the adjustment of the two market locations to exchange rate shocks. This is an interesting result by itself.

To summarize the findings, the estimated models reveal that for most stocks price discovery largely occurs in the home market with a relatively small role for U.S. trading. However, results differ across firms and some firms cast a larger role for U.S. than home market price discovery. The cross-section models indicate that these differences are driven by differences in the liquidity of the U.S. market for different firms and the extent of their multinational activity. Liquidity is measured by the following variables: NYSE market capitalization, NYSE/home turnover, NYSE/home volume, and the NYSE/home spread. Multinational activity is measured by the ratio of a firm's sales in the United States to its sales in the home market. The more liquid is U.S. trading in a stock and the greater the multinational activity of a firm, the larger the role for U.S. price discovery relative to the home market. With respect to the exchange rate effects, it appears that U.S. prices bear more of the burden of adjustment to an exchange rate shock than the home market. This is consistent with the general finding that the home market may be viewed as the primary market and the U.S. is the derivative market. For most firms, U.S. prices follow the home market prices and this leader-follower relationship is reflected in the U.S. price incorporating the exchange rate effect as the home market price tends to be taken as given to the U.S. However, there are important exceptions to this rule so that the dynamics of international price discovery are more complex than previously thought.

The study is organized as follows: section II provides information on each of the stock markets studied and their trading mechanisms along with information on the firms in the sample. Section III offers a description of hypothesized equilibrium relationships 
and the role that liquidity may play in international price discovery. Section IV introduces the econometric methodology employed. Estimation results and discussion are presented in section V. A conclusion and summary is given in the final section VI.

\section{TRADING VENUES AND FIRMS}

This study involves data on stocks traded on five different exchanges in five different countries. The exchanges and countries are: the New York Stock Exchange (NYSE)/United States; The Toronto Stock Exchange (TSE)/Canada; the Xetra system operated by the Deutsche Börse/Germany; the London Stock Exchange (LSE)/Great Britain; and the Paris Bourse/France. These locations are chosen for analysis because they have trading hours that overlap U.S. trading hours and high-frequency intra-daily quote data are available. The goals of this study require data sampled at very high frequencies to reveal the causality present in the data (if any). So daily data, which is available for all exchanges, would not be useful.

A brief summary of each trading venue is provided in Table 1. Key aspects of each market are as follows:

- New York The New York Stock Exchange (NYSE) is an auction market where each stock is assigned to a specialist who acts as a market maker. The specialist is obligated to maintain an orderly market in each stock, providing liquidity when needed. The NYSE also has an "upstairs market" where institutions trade large blocks of stocks apart from the primary market. Trading hours are from 9:30-16:00 New York time. The S\&P 500 
is a popular index of stock prices for U.S. trading. Trading occurs in U.S. dollars. At the time of our 1999 sample, the minimum price increment permitted was $\$ 1 / 16$. Now the minimum tick size is $\$ 0.01$.

- Frankfurt The largest trading platform for German blue chip stocks is the Xetra system maintained by the Deutsche Börse. It is an anonymous automated continuous auction system with call auctions at the open and the close. There exist parallel market maker systems, similar to the NYSE, of which the floor of the Frankfurt Stock Exchange is the largest. However, these alternative venues are relatively unimportant, especially regarding the liquid blue-chip stocks studied in this paper. Unlike the NYSE, Xetra does not employ dedicated providers of liquidity for bluechip stocks (for less liquid stocks there exist so-called dedicated sponsors who act as market makers). Until September 17, 1999, Xetra trading hours were from 8:30-17:00 local time. From September 20, 1999 on, trading hours were shifted to 9:00-17:30. Trading occurs in euros and the minimum price increment is $€ 0.01$. The DAX is the benchmark index of German equity trading and is made up of the top 30 blue chip companies.

- London The London Stock Exchange (LSE) is a dealer market with an electronic order book, SETS, used to trade blue-chip stocks. The LSE has no separate market for block trades like the upstairs market on the NYSE. Large trades are transacted on exchange but may be negotiated by telephone or through the order book. There are market makers assigned to particular stocks who have an obligation to quote bid-ask prices for 
normal quantities during official trading hours. ${ }^{2}$ Trading hours are from 8:00-16:30 London time. The major index of London trading is the FTSE 100. Trading is in British pounds and the minimum price increment depends upon the price of a security. Price ranges and minimum increments are: $0-9.99,0.0001 ; 10-499.75,0.25 ; 500-999.50,0.5$; and $1000+, 1$.

- Paris At the time of our 1999 sample, the Paris stock exchange was operated by the Paris Bourse. In September 2000, the Paris, Amsterdam, and Brussels exchanges formed an alliance to create Euronext. Trading in Paris is via an electronic order book, the CAC system, and is a dealership market. Trading hours are from 9:00-17:30 Paris time. The benchmark Paris index is the CAC 40. Trading is in euros and the minimum price increment depends upon the price of a security. Price ranges and minimum increments are 0.01-49.99, 0.01; 50-99.95, 0.05; 100-499.90, 0.10 ; and $500+, 0.50$.

- Toronto The Toronto Stock Exchange (TSE) is an auction market like the NYSE. Each stock is assigned to a registered trader who is obliged to act as a market maker, providing liquidity and an orderly market. Unlike the NYSE, trading at the TSE is completely electronic with no floor trading. At the time of our sample, the trading platform was the CATS system. In 2001 CATS was replaced by a new higher capacity TSX system. CATS was much like the CAC system in Paris. The major difference between

\footnotetext{
${ }^{2}$ The "normal" quantity or "normal market size" is set by the exchange for each security and is approximately $2.5 \%$ of average daily trading volume.
} 
Paris and Toronto is the presence of the market maker in Toronto. The market maker has the obligation to fill eligible market orders and tradable limit orders up to a specified number of shares (the minimum guaranteed fill) when an order cannot be filled from the order book. Trading hours are from 9:30-16:00 Toronto time. The S\&P TSX is the dominant index of Toronto trading. Trading occurs in Canadian dollars and the minimum price increment is $\mathrm{C} \$ 0.005$ for stocks selling for less than $\mathrm{C} \$ 0.50$ and C\$0.01 otherwise.

Most firms that list their shares in the United States do so with an American Depositary Receipt (ADR). ADRs are issued by a depositary bank accumulating shares of the underlying foreign stock. ADRs are issued at a fixed multiple relative to the underlying shares (like 5 ADRs per underlying share of Alcatel or 1 ADR per 6 underlying shares of BP Amoco). They tend to trade in a very limited range around the price of the underlying share, exchange-rate adjusted. However, ADRs and underlying shares are close, but not perfect, substitutes. First, they are priced in U.S. dollars and trade and settle just as any other stock in the United States. The dollar price of the ADR will differ from the home market price by a factor incorporating the exchange rate. In addition, foreign exchange risk might influence the differential between the ADR and home market share prices. One can, in principle, arbitrage the price difference between the ADR and underlying shares by new ADR issues or cancellations. This is not a riskless arbitrage due to the time required to convert underlying shares into ADRs or cancel ADRs and convert into underlying shares. In addition, there are conversion fees, the 
presence of the intermediary depositary bank, and possible voting and other corporate control rights that may differ between holders of the underlying shares and holders of the ADRs. For these reasons, ADRs are not perfect substitutes for the underlying shares. ${ }^{3}$ Beyond the issue of substitutability, there may be "limits to arbitrage" as discussed by Shleifer and Vishny (1997) where noise traders push prices away from fundamental values. However, considering the situation where two stocks are traded simultaneously in real time in different market locations, we expect the law of one price to hold so that the prices of the two assets move closely together over time.

Most of the firms in our sample are traded as ADRs in the United States. However, DaimlerChrysler (DCX) is traded in the United States as a global registered share (GRS), sometimes called a "global ordinary." This is a single security that is traded globally although it is quoted and settled in the respective local currency. GRSs differ from ADRs in that they do not involve a depositary intermediary and have no issues of conversion between different forms since the same security is traded internationally. Since the GRS is quoted in local currency in each market location, prices will differ across markets by an exchange rate factor. In general, global ordinary shares should be very close substitutes across international markets as they allow all stockholders to participate in corporate matters (dividends, distributions, and control issues) regardless of their location. They may not be perfect substitutes since there is local settlement and there may be less than perfect coordination across the multinational settlement institutions involving transfer and clearance issues. However, we would expect the two

\footnotetext{
${ }^{3}$ Gagnon and Karolyi (2003) have an extensive discussion of differences between ADRs and underlying shares and the issues involved in arbitraging this market.
} 
prices to move together even more closely than in the case of an ADR and its underlying share.

In addition, to DaimlerChrysler, all Canadian firms traded in the United States are listed as ordinary shares. One might think that Canadian ordinary shares trading in the United States may be more fungible with the home market than ADRs since the certificates traded in both countries are identical and there are no conversion fees. Our empirical work below will provide evidence on the degree to which U.S. and Canadian prices move together relative to prices of other countries' shares.

\section{DATA}

For the purpose of this study, we focus on bid and ask quotes submitted during the period of continuous trading in each market. Table 1 indicates that the intersection of the continuous trading hours of all exchanges is from 9:30-11:00 New York time. As a result, the empirical work will focus on this common interval of time for all markets.

Trading occurs in U.S. dollars in New York, Canadian dollars in Toronto, British pounds in London, and euro in Frankfurt and Paris. As a result, the models of price discovery will require exchange rates to link the U.S. dollar prices to prices in the other countries. Changes in exchange rates require a change in the U.S. and/or home market stock prices in order to preserve the law of one price and avoid arbitrage opportunities.

In order to avoid the problem of infrequent quoting, we focus on the firms from each home market that are most heavily traded on the NYSE. If we employed more thinly traded stocks, then we would have a problem of many "data holes" in our sample which 
would bias the results due to non-synchronous quoting in the home market and New York. Table 2 lists the firms and number of shares traded on the NYSE in 1999 along with the dollar value of this trade. The sample contains five firms traded in Toronto, four from Paris, three from Frankfurt, and five from London. These were the top-traded firms from each home market and there was a fairly steep drop-off in trading volume at the next lower firms. In 1999, the total number of firms listed on the NYSE from these countries was: Canada, 70; U.K., 46; France, 16; and Germany, 9.

While Canadian trading overlaps the entire New York trading day, the European markets only overlap the New York morning. We use the same sample period for all firms so that we have the same number of observations and hold everything constant other than the firm used for estimation. The New York data are from the TAQ data set available from the NYSE. Frankfurt data are proprietary data from the XETRA trading system of the Deutsche Börse. London data are the tick data set available from the London Stock Exchange. Paris trade and quote data were obtained from Paul Labys, who assembled the data set for other purposes. Toronto data are the Equity Trades and Quotes data set from the Toronto Stock Exchange. The intradaily exchange rates were obtained from Olsen Data in Zurich and are indicative quotes as posted by Reuters.

Table 3 provides basic trading information for each firm. The first column lists the NYSE stock symbols for each firm (Table 2 linked symbols with firm names). The second column provides the conversion ratios between ADRs and the underlying homemarket shares at the beginning of our sample. For instance, 12 SAP ADRs are equivalent to 1 share of SAP in Frankfurt during our sample period. Following a 3 to 1 stock split on 1 May, 2000, SAP ADRs now trade at a 4 to 1 ratio against the German shares. Stock 
splits occurring during our sample period are: NT (1:2 on August 13 on TSE and August 20 on NYSE); VOD (1:5 on October 1 at LSE and October 4 on NYSE); and BPA (1:2 on October 1 on both LSE and NYSE). In the empirical work that follows, the NYSE prices are adjusted by the appropriate conversion rate to be comparable to the underlying share prices. The third column of Table 3 lists the home market of each firm. The next two columns show the average relative spreads at home and on the NYSE. These are computed by taking sample averages of the spreads relative to the mid-quotes over the first 1.5 hours of New York trading. Volume and turnover data are reported in the remaining columns of Table 3. This average daily information is reported for the home market and the NYSE and for the overlap period of the New York morning as well as all day. Turnover is expressed in U.S. dollars using the sample average exchange rates to convert home market trade into dollars. For most firms, home market trading is heavier than New York trading. However, Canadian firms trade more in New York than at home. In addition, STM trades more in New York than Paris during the New York morning, but over the entire trading day, Paris trades STM more than New York.

Table 3 provides a portrait of the home market as the primary market for most firms with New York the derivative market. However, one can see that the difference between New York and home market trading activity differs greatly across firms. Next we turn to a more detailed description of the sampling methodology.

All asset price series are in logarithms of the average of the bid and ask prices. The asset prices were sampled at 10-second intervals to assemble the basic data set. The choice of sampling interval was made with the issue of contemporaneous correlation in mind. There can be one-way causality existing among variables at a high sampling 
frequency that dissolves into contemporaneous correlation at higher levels of temporal aggregation. Preliminary analysis was conducted over alternative sampling frequencies and we chose 10 seconds as being suitable relative to lower frequencies like 1 minute or 10 minutes. Preliminary estimates using 1-minute sampling revealed an increase in the information share for New York prices that is misleading in that the New York price change includes both the effects of NYSE price shocks as well as the effects of the NYSE price adjusting to exchange rate shocks. At a lower sampling frequency like 10 minutes, the contemporaneous correlation results in estimation bounds on the information shares so wide that one cannot clearly identify where price discovery occurs. At higher sampling frequencies than 10 seconds there was no gain in terms of reducing significant contemporaneous correlation, but there is a tradeoff with microstructural issues like nonsynchronous quoting or other sources of microstructure "noise" that makes 10 seconds preferable. An additional sampling issue is with regard to overnight returns and lags. We created a data set that started each day with observations on the dependent variables and lags so that no overnight returns were used and no lags reached back to prior days. For instance, if the model calls for 3 lags in the VEC, the dependent variable begins with the fourth observation of each day. The initial observation each day for each stock was determined by the first 10-second interval following the NYSE open containing a quote in both markets.

To ensure the integrity of the data set, screening of the time series was performed for each stock. It was determined that ELF shares in Paris experienced an unusual divergence from the New York price for a few days in September 1999. Further research revealed that this was probably due to the forthcoming merger with TotalFina (TOT). 
The offer period to exchange ELF shares for TOT shares began on September 23 in France and September 29 in the United States. Anyone buying shares of ELF after those dates was not able to participate in TOTs offer (19 TOT shares for 13 ELF shares). We omit all ELF quotes after September 27, 1999 in order to avoid any inferential problems arising from the merger-related price dynamics. Other than this brief period for ELF, no other unusual patterns in the data were found.

\section{PRICE FORMATION AND DETERMINANTS: METHODOLOGY}

\section{IV.A. Model of Price Discovery}

Equilibrium in the market for U.S.-traded shares and the underlying home-market shares involves the dollar price, the home-market price, and the exchange rate. We motivate the empirical analysis by first presenting a simple microstructure model where price discovery is assumed to occur in the most liquid market. We assume that the log of the exchange rate at time $t, E_{t}$, is exogenous with respect to U.S. and home-market shares and evolves as a random walk with innovation $u_{t}$ :

$$
E_{t}=E_{t-1}+u_{t}
$$

The log of the home-market share price, $P_{t}^{h}$, may follow a random walk and, thereby, introduce the innovation or random-walk component in the intrinsic value of the firm or it may follow the last observed $\log$ of the U.S. price, $P_{t-1}^{u}$, adjusted by the exchange rate, depending upon the liquidity of both trading venues:

$P_{t}^{h}=l_{h} P_{t-1}^{h}+\left(1-l_{h}\right)\left(P_{t-1}^{u}-E_{t-1}\right)+v_{t}$ 
where $v_{t}$ represents the home-market innovation and $l_{h}$ is an index of liquidity in the home market. It is assumed that traders weight prices in both markets by the liquidity existing. In the case where $l_{h}=1$, we have the random walk in the home-market price with no role for U.S. price discovery. In the other extreme where $l_{h}=0$, the home market price follows the U.S. price and all price discovery comes from the U.S. market. Further discussion related to determinants of $l_{h}$ will be given below.

The log of the U.S. price, $P_{t}^{u}$, may adjust to the last observed exchange rate and home-market price, or it may introduce the random-walk component in the value of the firm as its innovation, $w_{t}$, depending upon the liquidity of both trading venues:

$$
P_{t}^{u}=l_{h}\left(E_{t-1}+P_{t-1}^{h}\right)+\left(1-l_{h}\right) P_{t-1}^{u}+w_{t}
$$

In the event that $l_{h}=1$, price discovery occurs in the home market and the U.S. is the derivative market. If $l_{h}=0$, then price discovery occurs in the U.S. market and the home market is the derivative market. The innovations $u_{t}, v_{t}$, and $w_{t}$ are assumed to be both serially and contemporaneously uncorrelated with zero mean.

Arbitrage would result in the two stock prices, denominated in the same currency, moving closely together over time. If we subtract the $\log$ of the U.S. price from the $\log$ of the dollar value of a home-market share we have:

$$
E_{t}+P_{t}^{h}-P_{t}^{u}=u_{t}+v_{t}-w_{t}
$$

Since the linear combination of the log exchange rate, log home-market price, and log U.S. price is stationary, $E_{t}, P_{t}^{h}$, and $P_{t}^{u}$ are cointegrated with cointegrating vector $A^{\prime}=\left[\begin{array}{ll}1 & 1\end{array}-1\right]$. It is easily seen that in the simple model of equations (1)-(3) only the 
primary market innovations $v$ or $w$ and the exchange rate innovations $u$ determine the long run development of the derivative market price. For instance, if the home market is the primary market and the U.S. is the derivative market, then both the home market price and the exchange rate are completely determined by their own innovations, whereas the U.S. market innovations $w$ exert only a transitory effect on the U.S. price and do not influence the home market price and the exchange rate at all. In this case, price discovery for the stock is exclusively taking place in the home market. In our empirical model, however, we allow the innovations of both home market price, exchange rate, and U.S. market price to exert permanent effects on all three price series. However, the magnitude of the permanent effects are allowed to be different and estimated empirically so that the data will reveal where price discovery occurs.

For the general model employed in our empirical analysis, we maintain the assumption of the existence of one cointegrating relation between $E_{t}, P_{t}^{h}$, and $P_{t}^{u}$ with cointegrating vector $A^{\prime}=\left[\begin{array}{lll}1 & 1 & -1\end{array}\right]$. We further assume that the vector $P_{t}=\left(E_{t}, P_{t}^{h}, P_{t}^{u}\right)^{\prime}$ can be represented by a nonstationary vector autoregression of the form:

$$
P_{t}=\beta+\phi_{1} P_{t-1}+\phi_{2} P_{t-2}+\ldots+\phi_{q} P_{t-q}+\varepsilon_{t}
$$

where $\varepsilon_{t}$ is zero-mean white noise with covariance matrix $\Omega$. From the Granger Representation Theorem (Engle and Granger, 1987) we know that if there are cointegrating relations among the elements of $P$, there exists an error correction representation of the form:

$$
\Delta P_{t}=\alpha+B Z_{t-1}+\delta_{1} \Delta P_{t-1}+\delta_{2} \Delta P_{t-2}+\ldots+\Delta P_{t-q+1}+\varepsilon_{t}
$$

where $Z_{t-1}=A^{\prime} P_{t-1}$. 
Section IV.B will provide more details on the econometric methodology employed to identify where price discovery occurs. Before moving to that section, we first discuss the likely determinants of the weights, $l_{h}$, determining whether the home or U.S. market is the primary trading venue where price discovery occurs. A recent paper by Baruch, Karolyi, and Lemmon (2003) provides a theoretical model and empirical support for trading volume of cross-listed firms to be concentrated in the market with the highest correlation of cross-listed asset returns with other asset returns in that market. As the authors point out, the determination of such asset returns remains to be explained. Our expectation is that the liquidity of each market should be a major factor in determining location of price discovery as well as trading volume. As Harris (2003, p. 243) states: "How informative prices are depends on the costs of acquiring information and on how much liquidity is available to informed traders. If information is expensive, or the market is not liquid, prices will not be very informative." The relation between informativeness of price and liquidity is also supported by finance theory as seen in an early paper like Admati and Pfleiderer (1988) or Hong and Rady (2002). In such models, price innovations are smaller, the deeper or more liquid the market. So any given change has a larger information component in the more liquid market. Models like Foucault (1999) or Foucault, Kadan, and Kandel (2001) have limit orders of liquidity traders priced with wider spreads as the uncertainty regarding information increases. The market location where information is embedded in price should have greater liquidity than the other market. Harris, McInish, and Wood (2003) make a connection between liquidity, information, and home bias in international investment. Domestic investors may be better informed about and better able to monitor local firms than foreign firms. They point to 
studies by Low (1993), Brennan and Cao (1997), and Coval (1996) as offering support for such information-based home bias.

The cross-section models to be estimated will test the hypothesis that price discovery in the U.S. or the home market differs in a systematic manner across firms with liquidity of each trading venue.

\section{IV.B. Inference on Price Discovery and Determinants}

There are two issues to be addressed by the empirical work: 1) what is the contribution of each market to price discovery, and 2) what determines the differences across firms. We will discuss the econometric methodology utilized for each of these issues in turn. The first issue is addressed by the information shares approach introduced by Hasbrouck (1995). Then, once having estimates of the share of each market in the price discovery process, logistic regression models are estimated to explore the determinants of price discovery across firms.

We begin by writing the cointegrated system in a vector moving average (VMA) representation:

$\Delta P_{t}=\Psi(L) \varepsilon_{t}=\varepsilon_{t}+\psi 1 \varepsilon_{t-1}+\psi 2 \varepsilon_{t-2}+\ldots$

Cointegration of the three price series with cointegrating vector $A$ ' implies that $A^{\prime} \Psi(1)=0$, where $\Psi(1)=I+\psi_{1}+\psi_{2}+\ldots$. The estimation of the $\Psi(1)$ matrix is the cornerstone of the analysis since this matrix contains information about the magnitude of the permanent effect that each of the innovations exerts on the long run dynamics of the three prices. The econometric methodology to estimate $\Psi(1)$ involves three steps. First, 
the Schwarz information criterion (SIC) is employed to identify the appropriate lag length in equation (6). In the second step we estimate a VEC model with the identified lag length, which is then used in a dynamic simulation to estimate the VMA parameters in (7) and the elements of the $\Psi(1)$ matrix. Once $\Psi(1)$ is estimated, we can infer the share of information associated with innovations to each market. An appendix provides more details on the econometric methodology.

Once the information shares for each firm $i, I_{i}$, have been found, we then use these to create dependent variables for logistic regression models. Information shares are left censored at 0 and right censored at 1 , so the parameters are estimated via the logistic regression model:

$\ln \left(\frac{I_{i}}{1-I_{i}}\right)=x_{i}^{\prime} \beta+\varepsilon_{i}$

where $x$ is a vector of explanatory variables, $\beta$ is a vector of parameters to be estimated, and $\varepsilon$ is a random error term. Equation (8) is estimated via ordinary least squares with standard errors computed using the White heteroskedasticity-consistent covariance matrix.

\section{ESTIMATION RESULTS}

\section{V.A. Information Shares in Price Discovery: Time-Series Evidence}

Augmented Dickey-Fuller tests revealed unit roots in the log of each asset price and the variables were identified as being I(1). Johansen cointegration tests were performed and the results clearly support the hypothesis of one cointegrating vector 
among the 3 variables. With the variables ordered as exchange rate, home-market price, and U.S. price, the estimated cointegrating vectors are close to the vector $A^{\prime}=\left[\begin{array}{lll}1 & 1 & -1\end{array}\right]$ indicated by theory. Due to the number of firms in the sample, estimates of the cointegration models are not reported. Instead, we focus on the estimates of the VEC equation and the associated information shares. The choice of lag length was determined by the Schwarz Information Criterion (SIC). We started with 18 lags, which is 3 minutes in a sample with observations at 10 -second intervals. Then, holding the number of observations constant, we estimated the VEC at each shorter lag length down to 1 lag to determine the lag structure that minimized the SIC. Lag lengths range from 3 for ALA, ELF, DT, and SAP to 7 for VO.

Estimation precision is assessed employing the bootstrap method suggested by Li and Maddala (1997). In order not to distort the dynamic properties of the cointegrated system we bootstrap from the residuals of our estimated VEC models rather than from the actual data. ${ }^{4}$ More precisely, the estimated residuals are re-sampled by drawing observations randomly with replacement and then building a new vector of observations on the data from the innovations and the lagged values of the dependent variables. From the new set of observations, parameters are re-estimated. This process is repeated 1,000 times to generate the empirical distributions for the parameters of interest. The bootstrap procedure offers the chance to obtain parameter standard errors (and in fact estimates of the whole distribution) when they are not available analytically. We thus overcome the drawback that the precision regarding estimates of the information shares cannot be assessed analytically.

\footnotetext{
${ }^{4}$ Given the dynamic structure of the model, bootstrapping the dependent variables would distort the true relationships when lagged dependent variables appear on the right-hand-side of the equation.
} 
As explained in the appendix, the triangularization of the innovation variancecovariance matrix results in an upper bound on the estimated information share for the variable that comes first in the ordering and a lower bound on the information share for the variable that comes last in the ordering. We will later address this issue by estimating the upper and lower bounds of information shares. First, an ordering of exchange rate, home-market price, and U.S. price is used to estimate the information shares and then a reordering with exchange rate, U.S. price, and home-market price is used and the average of the two information shares is reported in Figure 1.

The figure reports the proportion of the innovation variance in the price of asset $i$ that is attributed to innovations in the price of asset $j$, where the proportions are measured on the vertical axis. The top left of the Figure has asset $i$ as the U.S. price and asset $j$ is the home market price. The figure plots the information shares for each firm. The numbers given in parentheses are the standard errors of the estimated information shares. For instance, in the top left figure of Figure 1, we see that price innovations for TOT in Paris account for about 0.9 of the U.S. price innovation variance and the standard error of this estimate is 0.022 . The data plotted in the top left figure shows that the home-market information shares range from about 0.9 for TOT, ALA, ELF, and DT to about 0.4 for BPA. In general, the information shares of home market prices for the U.S. price are greater than 50 percent with only two exceptions, BPA and VO. The top right of the figure contains the estimates and standard errors for the information share of U.S. price innovations on the U.S. price. We can see the close relationship between the two top figures in Figure 1. BPA and VO have information shares greater than 50 percent in the top right figure while the other firms are generally much less than 0.5 . 
The middle row of Figure 1 presents the estimated information shares for the home and U.S. price innovations on the home market price. Once again it is seen that only BPA and VO have home-market price innovation information shares less (greater) than 50 percent on the home (U.S.) market price.

The bottom row of Figure 1 plots the average information shares attributable to exchange rate innovations on the home and U.S. price. It is clear that the exchange rate plays a small role in price discovery for these internationally-listed firms. The bottom left figure shows that the largest information share for exchange rate innovations on the home market price is estimated to be about 3 percent for BPA with much smaller values for the other firms (the average across all firms is 0.006). The bottom right figure shows that the exchange rate information shares are larger for the U.S. price (the average across all firms is 0.026). The U.S. price responds more to an exchange rate shock than does the home-market price.

Figure 1 clearly shows the dominance of the home market price in price discovery. The information shares for U.S. price innovations are seen to be somewhat of a mirror image of the home-price information shares. The higher the information share of the home-market price innovations in explaining home-market price, the lower the U.S. information shares.

We do not report a figure for the information shares related to explaining the variance of innovations in the exchange rate. The exchange rate innovations account for essentially all price discovery in the exchange rate with the stock prices contributing essentially nothing. This is consistent with the exchange rate being exogenous with respect to the two stock prices and is reflected in the information share of the exchange 
rate in explaining the variance of exchange rate innovations equaling one while the information shares for the home-market and U.S. prices are essentially zero. This exogeneity of the exchange rate is supported across all firms.

The hypothesis that the home market is the primary market and the U.S. the derivative market would be consistent with a larger role for price discovery in the home market than in the United States. Figure 1 indicates that this is clearly true on average for the firms in our sample. However, 9 firms have a sizeable (information share greater than 20 percent) role for U.S. price discovery and 2 firms (BPA and VO) have a larger information share for U.S. price innovations than home-market (London and Toronto) price innovations. The interesting question of what explains the differences across firms will be addressed in the cross-section analysis below.

As already mentioned, the exchange rates appear to be exogenous as there is no economically significant role for the stock prices in exchange rate price discovery. Yet how do the stock prices adjust to exchange rate shocks? To avoid arbitrage and restore the law of one price, the stock prices must change following a change in the exchange rate. Comparing the exchange rate information shares for home-market and U.S. prices underlying the plots in Figure 1, it is clear that generally the U.S. price bears the burden of adjustment to an exchange rate shock as the values of the exchange rate information shares in explaining U.S. prices are significantly greater than those for home-market prices in all but 3 cases. The exceptions for BPA and VO, are consistent with the U.S. being the primary market for these stocks. In addition, the exchange rate information share in the U.S. price is slightly larger than that for the home-market price for AL. 
Summarizing the results so far, price discovery for most firms occurs largely in the home market with a small, but statistically significant role for U.S. prices. This is consistent with the home market being the primary market for most stocks with U.S. trading following the home market. However, the U.S. has the dominant price discovery role for 2 firms and has more than a 20 percent information share for 7 more firms. The exchange rate evidence indicates that the exchange rate may be considered to be exogenous with respect to the stock prices. The stock price adjustment to an exchange rate shock occurs largely in the market with the dominant information share. In all but three cases, the U.S. price does most of the adjusting following a shock to the exchange rate. This is additional evidence that the home market is generally the primary market and the derivative market takes the stock price as given in the home market and then follows that price and also accommodates any exchange rate change. So with few exceptions, it is apparent that exchange rate shocks are more important in understanding the intradaily evolution of New York prices of internationally cross-listed firms than the prices of these firms in their home-market.

\section{V.B. Information Shares in Price Discovery: Cross-Firm Evidence}

The striking question that emerges from the results reported in Figure 1 is why firms differ so much in terms of price discovery at home and in the United States. The home market information shares for home market prices range from about 98 percent for DT to about 40 percent for BPA. The associated U.S. information shares for home market prices range from less than 1 percent to about 60 percent, respectively. In 
between these extremes, we see that in some cases, there is a sizeable role for U.S. price innovations in home market price discovery while in other cases, there is but a small role.

We now analyze the determinants of the cross-firm differences using the logisticregression model that was described in equation (8). An extensive search for data on explanatory variables was undertaken. The focus was on assembling a data set that would include measures of liquidity in both stock markets, the extent to which a firm was mainly a domestic firm rather than a multinational, and the "U.S. following" that firms have. Data on the following variables were obtained:

- New York market capitalization (from the NYSE)

- NYSE and home market turnover (from NYSE and home market)

- NYSE and home market volume (from NYSE and home market)

- NYSE and home market bid-ask spreads (from NYSE and home market)

- Sales in the U.S. and the home market (from Worldscope)

- U.S. analysts following (from $\mathrm{I} / \mathrm{B} / \mathrm{E} / \mathrm{S})^{5}$

- U.S. and non-U.S. fund holdings of NYSE listed shares (from Thompson Financial Spectrum)

As stated in section IV, since information shares are truncated at 0 and 1 , a logistic regression model is employed. Specifically, the dependent variable is the information share in home-market prices that is attributed to innovations in New York prices. These data are found in the section labeled "Info share attributable to US market innovations (home market))" in Figure 1.

\footnotetext{
${ }^{5}$ Specifically, this is the number of U.S. analysts making a recommendation on a stock in 1999. Jennifer Juergens provided valuable advice in identifying the firms and locations of analysts.
} 
A specification search was carried out by first regressing the U.S. information share on each of the potential explanatory variables listed above. Due to the limited number of degrees of freedom, it was not feasible to estimate a regression with all explanatory variables included at one time. The initial set of regressions yielded the results reported in Table 4 . The estimates reported in Table 4 are for regressions including only a constant term and the variables each entered individually. It is clear from the P-values in Table 4 that all four of the liquidity variables are statistically significant as is the ratio of U.S. to home sales. The latter variable is a measure of the multinational activity of the firms.

Based upon this initial specification search, the variables related to the U.S. following of the firms were omitted from further consideration due to their lack of statistical significance as reported in Table 4. In addition, the turnover and volume variables were highly collinear so volume was omitted from further analysis. A model including the three remaining liquidity variables and the Home/U.S. sales variable is then estimated as reported in Table 5. Only the NYSE/Home turnover and Home/U.S. sales variables remain statistically significant. There is obvious collinearity among the liquidity variables. A likelihood ratio test for the joint significance of the NYSE market capitalization and relative spread variables results in a p-value of 0.24 . We therefore delete the variables that enter insignificantly in Table 5 to form a final specification with just NYSE/Home turnover and Home/U.S. sales as explanatory variables. Estimation results are reported in Table 6 . Both variables are highly significant determinants of the differences in information shares across firms. 
The results support the following inference: the greater the NYSE trading activity relative to the home market, the greater the share of price discovery in New York; and the smaller a firm's sales in its home market relative to its U.S. sales, the greater the New York price discovery. Note that this model is able to explain a large proportion of the cross-firm variation in information shares.

\section{SUMMARY AND CONCLUSIONS}

This paper addresses two issues: 1) Where does price discovery occur for firms that are traded simultaneously in New York and in other markets in other countries and 2) what explains the differences across firms in the share of price discovery that occurs in New York? The short answer to the first question is that most firms have the largest fraction of price discovery occur at home with New York taking a relatively small role. However, the data reveal important exceptions to this finding. It is simply not true that New York trading always follows the home market and there is no significant role for price discovery to occur in New York. The answer to the second question is found by modeling the information share of New York trading in price discovery of home-market prices across firms as a function of variables related to New York liquidity relative to liquidity in the home market, indicators of multinational activity, and a stock's U.S. following. The data provide strong support that liquidity and multinational activity are the important factors. All liquidity proxies have statistically significant explanatory power. So also do sales in the home market relative to the U.S. In particular, the smaller a firm's sales at home relative to those in the U.S. and the greater NYSE trading activity 
relative to home market trading activity in a firm, the greater the role for NYSE price discovery for that firm.

An additional issue of interest arises from our modeling strategy of allowing an independent effect for the exchange rate. Past studies have typically used the exchange rate to convert prices of one market into the same currency units of another market and then proceeded to analyze the link between the prices in both markets. For instance, rather than model a three variable system of, say, the price of STM in Paris in euros, the price in New York in dollars, and the dollar/euro exchange rate, it is typical for researchers to convert the dollar price into euros with the exchange rate and then model the links between the Paris and New York price. However, this then allows the New York price to include the exchange rate innovations and may bias the results regarding true causality. In earlier work, not reported here, we found that the bias is increasing in exchange rate volatility. Such bias does not enter into the results reported in this study. These results indicate strong support for the exchange rate as an exogenous variable in the cross-country pricing of a firm's stock. Furthermore, our results indicate that the NYSE price usually bears the burden of adjustment to the law of one price following an exchange rate shock. This is interpreted as further evidence that the NYSE is typically the derivative market for non-U.S. firms and the home market is the primary market. However, it is important to realize that this is not a universal truth. For those firms where the NYSE has the dominant price discovery role, the exchange rate adjustment comes more from the home market than the NYSE.

Overall, the results indicate that the nature of price discovery across international markets during the time of trading overlap is richer and more complex than previously 
realized. While the home market is typically where the majority of price discovery occurs, there are significant exceptions to this rule. 


\section{REFERENCES}

Admati, A.R., and Pfleiderer, P., 1988, “A Theory of Intraday Patterns: Volume and Price Variability," Review of Financial Studies, 1, 3-40.

Baruch, S., A. Karolyi, and M.L. Lemmon, 2003, "Multi-Market Trading and Liquidity: Theory and Evidence,” Working Paper, Ohio State University.

Ding, D.K., F.H. deB. Harris, S.T. Lau, and T.H. McInish, 1999, “An Investigation of Price Discovery in Informationally-Linked Markets: Equity Trading in Malaysia and Singapore," Journal of Multinational Financial Management, 9, 317-329.

Eun, C.S., and S. Sabherwal, 2003, "Price Discovery for Internationally Traded Securities: Evidence from the U.S.-Listed Canadian Stocks.” Journal of Finance, $58,549-576$.

Gagnon, L., and G.A. Karolyi, 2003, "Multi-Market Trading and Arbitrage.” Working Paper, Ohio State University.

Grammig, J., M. Melvin, and C. Schlag, forthcoming, "Internationally Cross-Listed Stock Prices During Overlapping Trading Hours: Price Discovery and Exchange Rate Effects," Journal of Empirical Finance.

Harris, L, 2003, Trading and Exchanges, Oxford: Oxford University Press.

Hong, H., and S. Rady, 2002, "Strategic Trading and Learning About Liquidity," Journal of Financial Markets, 5, 419-450.

Kim, M., A.C. Szakmary, and I. Mathur, 2000, Price transmission dynamics between ADRs and their underlying foreign securities, Journal of Banking and 
Finance 24, 1359-1382.

Kato, K., S. Linn, and J. Schallheim, 1990, Are there arbitrage opportunities in the market for American Depository Receipts? Journal of International Financial Markets, Institutions, and Money 1, 73-89.

Lau, S.T., and J.D. Diltz, 1994, Stock returns and the transfer of information between the New York and Tokyo stock exchanges, Journal of International Money and Finance 13, 211-222.

Lieberman, O, U. Ben-Zion, and S. Hauser, 1999, A characterization of the price behavior of international dual stocks: an error correction approach, Journal of International Money and Finance 18, 289-304.

Shleifer, A. and R.W. Vishny, 1997, The limits of arbitrage, Journal of Finance 52, 3555.

Wang, S.S., O.M. Rui, and M. Firth, 2002, Return and volatility behavior of duallytraded stocks: the case of Hong Kong, Journal of International Money and Finance 21, 265-293. 


\section{APPENDIX}

From Stock and Watson's (1988) common trends representation of a cointegrated system it can be seen that the permanent impact of innovations on the three asset prices is given by the vector $\Psi(1) \varepsilon_{t}$. It is useful to write the components of this vector explicitly as: $\Psi(1) \varepsilon_{t}=\left[\begin{array}{lll}\psi_{11} & \psi_{12} & \psi_{13} \\ \psi_{21} & \psi_{22} & \psi_{23} \\ \psi_{31} & \psi_{32} & \psi_{33}\end{array}\right]\left[\begin{array}{c}\varepsilon_{t}^{e} \\ \varepsilon_{t}^{h} \\ \varepsilon_{t}^{u}\end{array}\right]$.

For example, with the elements in $P_{t}$ being ordered as $E_{t}, P_{t}^{h}$, and $P_{t}^{u}$, the first row of $\Psi(1) \varepsilon_{t}, \psi_{11} \varepsilon_{t}^{e}+\psi_{12} \varepsilon_{t}^{h}+\psi_{13} \varepsilon_{t}^{u}$, gives the long-run component of the innovations that is permanently impounded in the exchange rate. The permanent impact of a one unit innovation in price $j$ on price $i$ is given by $\psi_{i j}$. For instance, $\psi_{12} \varepsilon_{t}^{h}$ is the long-run impact of an innovation, $\varepsilon_{t}^{h}$, in the home-market price on the exchange rate random walk.

To find the information shares attributable to each market, we decompose the variance of long-run impacts $\operatorname{var}\left(\psi_{i 1} \varepsilon_{t}^{e}+\psi_{i 2} \varepsilon_{t}^{h}+\psi_{i 3} \varepsilon_{t}^{u}\right), i=1,2,3$. These variances can be found on the diagonal of $\psi \Omega \psi^{\prime}$. The information shares are obtained by a decomposition of each of the three variances into the contributions of each market.

In case of contemporaneous correlation among the innovations, it is not possible to identify an independent information share for each asset without further restrictions. 
To circumvent this problem, we follow the standard approach by using the Cholesky factorization of $\Omega$. This provides a lower triangular matrix $C$, where $\Omega=C^{\prime} C$. The Cholesky factorization is creating an orthogonalization by which one could, for example, first isolate the impact of the exchange rate innovation, then the home-market innovation conditioned on the exchange rate innovation, and then the U.S. innovation, conditioned on both of the other markets. In this recursive setting, one may think of the orthogonalized innovation in the U.S. market as being the residual of a regression of the U.S. innovation on the innovations in the exchange rate and home-market price. With a given ordering of markets, one now may compute the information share of market $j$ with respect to price series $i, S_{i j}$, as:

$S_{i j}=\left([\psi C]_{i j}\right)^{2} /\left(\psi \Omega \psi^{\prime}\right)_{i i}$.

This normalization guarantees that the information shares sum to unity for each price series. The Cholesky factorization will result in providing an upper bound on the share for the market ordered first and a lower bound for the share of the market ordered last. Hence, the resulting information shares will depend upon a specific ordering of the markets, and it is important to check that the qualitative results are robust across alternative orderings. 
Table 1

A Comparison of Trading Venues

\begin{tabular}{|c|c|c|c|c|c|}
\hline & New York & Frankfurt & London & Paris & Toronto \\
\hline Major Index & S\&P 500 & DAX & FTSE 100 & CAC 40 & $\begin{array}{l}\text { S\&P TSX } \\
\text { Composite }\end{array}$ \\
\hline Currency & U.S. dollar & euro & British pounds & euro & Canadian dollar \\
\hline Price Increments & $\begin{array}{l}\text { Now } \$ 0.01 \\
\text { for } 1999 \text { sample } \\
\text { period: } \$ 1 / 16\end{array}$ & $€ 0.01$ & $\begin{array}{l}\text { Stock price: } \\
0-9.9999, £ 0.0001 \\
10-499.75, £ 0.25 \\
500-999.50, £ 0.5 \\
\geq 1000, £ 1\end{array}$ & $\begin{array}{l}\text { Stock price: } \\
0.01-49.99, € 0.01 \\
50-99.95, € 0.05 \\
100-499.90, € 0.10 \\
\geq 500, € 0.50\end{array}$ & $\begin{array}{l}\text { Stock price: } \\
<0.50, \mathrm{C} \$ 0.005 \\
\geq 0.50, \mathrm{C} \$ 0.01\end{array}$ \\
\hline Trading System & $\begin{array}{l}\text { Market maker } \\
\text { specialists }\end{array}$ & $\begin{array}{l}\text { XETRA electronic } \\
\text { order book }\end{array}$ & $\begin{array}{l}\text { SETS electronic } \\
\text { order book }\end{array}$ & $\begin{array}{l}\text { Euronext electronic } \\
\text { order book }\end{array}$ & $\begin{array}{l}\text { Market maker } \\
\text { specialists }\end{array}$ \\
\hline $\begin{array}{l}\text { Trading Hours } \\
\text { (local time) }\end{array}$ & $9: 30-16: 00$ & $\begin{array}{l}\text { Now 9:00-17:30 } \\
\text { for 1999 sample } \\
\text { period: 9:00-17:00 }\end{array}$ & $8: 00-16: 30$ & $9: 00-17: 30$ & $9: 30-16: 00$ \\
\hline $\begin{array}{l}\text { Trading Hours } \\
\text { (New York time) }\end{array}$ & $9: 30-16: 00$ & $3: 00-11: 00$ & $3: 00-11: 30$ & $3: 00-11: 30$ & 9:30-16:00 \\
\hline
\end{tabular}




\section{Table 2}

\section{Most active firms for NYSE trading in 1999}

$\underline{\text { Shares traded (millions) } \quad \text { Value (million \$) }}$

Toronto:

Nortel (NT) 607

Seagram (VO) 257

Barrick Gold Corp (ABX) 381

Newbridge Networks (NN) 272

Alcan Aluminium (AL) 182

41,645

12,644

7,325

7,156

5,775

Paris:

STMicroelectronics (STM) 124

11,589

Alcatel (ALA)

174

4,871

TOTALFina (TOT)

71

Elf Aquitaine (ELF)

52

4,482

3,996

Frankfurt:

DaimlerChrysler (DCX) $\quad 170$

14,794

SAP (SAP)

196

6,800

Deutsche Telekom (DT) 38

1,655

\section{London:}

Vodafone (VOD) 383

BP Amoco (BPA) 476

43,858

41,443

SmithKline Beecham (SBH) 152

10,027

Glaxo Wellcome (GLX) 111

6,537

AstraZeneca (AZN)

98

4,085 
Table 3

Descriptive Statistics for Firms and Markets

Summary statistics are reported for German, Canadian, British, and French companies with the largest NYSE trading volume. The sample period ranges from August 1, 1999 to October 31, 1999. Relative spreads are computed by taking sample averages of the ratio of spread to mid-quotes at the 10 second sampling interval considering only the spreads and mid-quotes during the daily trading overlap period of the first 1.5 hours of New York trading. Trade volume and turnover are reported both for the New York morning and all day. The trade turnover is expressed in US \$ by using the sample average of the respective

exchange rate to convert from local currencies. Trade volumes were computed by converting the NYSE traded ADRs into home-market equivalents. The column $A D R$ ratio reports the conversion rate from ADRs into home-market stock. These ADR ratios refer to the beginning of the sample periods, before any stock splits. Stock splits occurred for NT (1:2 implemented August 13, 1999 on TSE and August 20, 1999 on NYSE), for VOD (1:5, implemented after October 1, 1999 at LSE and after October 4, 1999 at NYSE) and for BPA (1:2, implemented after October 1, 1999 at LSE and NYSE). DCX is traded as a globally registered share (GRS), i.e the unit of stock is the same at both the home market and the NYSE. Trade volumes refer to units of stocks at the beginning of the sample period, before eventual stock splits.

\begin{tabular}{|c|c|c|c|c|c|c|c|c|c|c|c|c|}
\hline \multirow[b]{2}{*}{ Stock } & \multirow[b]{2}{*}{$\begin{array}{l}\mathrm{ADR} \\
\text { ratio }\end{array}$} & \multirow[b]{2}{*}{$\begin{array}{l}\text { Home } \\
\text { market }\end{array}$} & \multirow[b]{2}{*}{\begin{tabular}{|c|}
$\begin{array}{c}\text { Relative } \\
\text { spread home } \\
\text { market }\end{array}$ \\
\end{tabular}} & \multirow[b]{2}{*}{$\begin{array}{l}\text { Relative } \\
\text { spread } \\
\text { NYSE }\end{array}$} & \multicolumn{4}{|c|}{ First 1.5 hours of overlap } & \multicolumn{4}{|c|}{ Whole trading day } \\
\hline & & & & & $\begin{array}{l}\text { Trade volume } \\
\text { home market }\end{array}$ & $\begin{array}{l}\text { Trade } \\
\text { volume } \\
\text { NYSE } \\
\end{array}$ & $\begin{array}{c}\text { Turnover home } \\
\text { market }\end{array}$ & $\begin{array}{c}\text { Turnover } \\
\text { NYSE }\end{array}$ & $\begin{array}{l}\text { Trade volume } \\
\text { home market }\end{array}$ & $\begin{array}{c}\text { Trade volume } \\
\text { NYSE }\end{array}$ & $\begin{array}{c}\text { Turnover home } \\
\text { market }\end{array}$ & $\begin{array}{c}\text { Turnover } \\
\text { NYSE }\end{array}$ \\
\hline $\mathrm{DCX}$ & * & Xetra & $0.107 \%$ & $0.197 \%$ & 694,046 & 191,814 & $51,528,693$ & $14,228,694$ & $2,905,670$ & 484,184 & $215,366,677$ & $35,799,818$ \\
\hline DTE & $1: 1$ & Xetra & $0.166 \%$ & $0.361 \%$ & 875,623 & 46,698 & $37,580,050$ & $1,994,945$ & $3,747,518$ & 100,964 & $161,125,301$ & $4,307,691$ \\
\hline SAP & $12: 1$ & Xetra & $0.175 \%$ & $0.392 \%$ & 78,682 & 27,317 & $33,602,328$ & $11,859,883$ & 330,121 & 76,542 & $141,447,885$ & $33,199,945$ \\
\hline$A B X$ & $1: 1$ & TSE & $0.280 \%$ & $0.397 \%$ & 656,598 & 678,708 & $13,657,798$ & $14,108,793$ & $1,811,664$ & $1,882,666$ & $37,454,097$ & $38,959,813$ \\
\hline AL & $1: 1$ & TSE & $0.272 \%$ & $0.290 \%$ & 247,325 & 345,109 & $8,211,594$ & $11,462,946$ & 701,569 & 854,338 & $23,174,438$ & $28,329,124$ \\
\hline NT & $1: 1$ & TSE & $0.193 \%$ & $0.221 \%$ & 701,799 & 947,341 & $36,256,367$ & $51,326,652$ & $2,043,588$ & $2,870,513$ & $105,966,209$ & $154,431,852$ \\
\hline VO & $1: 1$ & TSE & $0.348 \%$ & $0.303 \%$ & 156,979 & 309,328 & $7,495,220$ & $14,617,631$ & 558,623 & 993,028 & $26,677,862$ & $46,833,469$ \\
\hline AZN & $1: 1$ & LSE & $0.191 \%$ & $0.299 \%$ & 646,448 & 154,541 & $32,646,959$ & $6,315,050$ & $2,975,335$ & 395,723 & $136,066,262$ & $16,264,166$ \\
\hline BPA & $1: 6$ & LSE & $0.193 \%$ & $0.129 \%$ & $3,684,905$ & $3,123,947$ & $48,988,226$ & $45,092,071$ & $13,807,599$ & $8,356,922$ & $194,712,299$ & $121,570,006$ \\
\hline GLX & $1: 2$ & LSE & $0.193 \%$ & $0.266 \%$ & $1,193,917$ & 326,431 & $39,243,013$ & $8,950,115$ & $5,496,750$ & 841,888 & $162,460,030$ & $23,002,738$ \\
\hline $\mathrm{SBH}$ & $1: 5$ & LSE & $0.277 \%$ & $0.261 \%$ & $1,999,612$ & $1,241,117$ & $29,828,594$ & $15,472,396$ & $9,394,953$ & $3,154,039$ & $127,110,541$ & $39,114,665$ \\
\hline VOD & $1: 10$ & LSE & $0.216 \%$ & $0.166 \%$ & $7,109,291$ & $6,309,281$ & $69,158,792$ & $69,300,596$ & $32,780,446$ & $19,087,688$ & $301,014,118$ & $203,257,944$ \\
\hline ALA & $5: 1$ & Paris & $0.154 \%$ & $0.424 \%$ & 188,520 & 30,942 & $27,447,956$ & $4,507,972$ & 650,620 & 105,683 & $94,607,842$ & $15,459,105$ \\
\hline STM & $1: 1$ & Paris & $0.182 \%$ & $0.249 \%$ & 333,169 & 354,409 & $25,394,057$ & $27,514,187$ & 959,302 & 790,316 & $73,398,025$ & $61,093,536$ \\
\hline TOT & $2: 1$ & Paris & $0.142 \%$ & $0.229 \%$ & 407,985 & 52,551 & $52,684,674$ & $6,775,357$ & $1,640,752$ & 155,484 & $213,098,811$ & $20,101,310$ \\
\hline
\end{tabular}




\section{Table 4}

\section{Determinants of Information Shares: Initial Specification Search}

This table summarizes logistic-regression results for information share models with a constant term and each of the variables listed in the table. Data are for 1999. The turnover, volume, and spreads data were computed during the first 1.5 hours of NYSE trading when all the other markets were also trading. The other trading venues include Frankfurt, London, Paris, and Toronto. The top-traded firms from each of

these 4 markets in terms of volume on the NYSE are included in the sample. This results in a sample of 17 firms. The White heteroskedasticity-consistent covariance matrix was used for computing standard errors.

\section{Variable}

Liquidity Indicators:

NYSE Market Capitalization

(NYSE/Home Turnover)

NYSE/Home Volume

NYSE spread/Home spread

Multinational Indicator:

\section{$\underline{\text { Coefficient }} \underline{\text { P-Value }} \quad \underline{\text { R-square }}$}

$0.00004 \quad 0.02 \quad 0.169$

0.00

1.476

0.00

0.512

$-1.520$

0.00

0.521

(U.S./home sales)

$-0.014$

0.00

0.357

U.S. Following:

No. of Analysts

0.191

0.26

0.099

U.S./non-U.S. fund holdings

0.847

0.68

0.013 


\section{Table 5 \\ Cross-Firm Estimation Results: Information Shares as a Function of Liquidity Indicators and Multinational Activity}

This table summarizes logistic-regression results for a model where the dependent variable is the information share of U.S. price innovations in explaining home-market prices for a cross-section of the most heavily traded firms on the NYSE from the following locations: Frankfurt, London, Paris, and Toronto. Data are for 1999. The turnover, volume and spreads data were computed during the first 1.5 hours of NYSE trading when all the other markets were also trading. The White heteroskedasticityconsistent covariance matrix was used for computing standard errors.

\section{Variable}

Constant

NYSE Market Capitalization

NYSE/Home Turnover

NYSE spread/Home spread

(Home/U.S. sales)

\section{Coefficient P-Value}

$-1.307$

0.202

$0.000009 \quad 0.706$

0.874

0.048

$-0.520$

0.253

$-0.009$

0.000

$$
\mathrm{R}^{2}=0.743
$$




\section{Table 6 \\ Cross-Firm Estimation Results: Information Shares as a Function of NYSE/Home Turnover and Home/U.S. Sales}

This table summarizes logistic-regression results for a model where the dependent variable is the information share of U.S. price innovations in explaining home-market prices for a cross-section of the most heavily traded firms on the NYSE from the following locations: Frankfurt, London, Paris, and Toronto. Data are for 1999. The White heteroskedasticity-consistent covariance matrix was used for computing standard errors.

$\underline{\text { Variable }}$

Constant

NYSE/Home Turnover

(Home/U.S. sales)

\section{Coefficient $\quad \underline{\text { P-Value }}$}

$-2.222$

1.230

$-0.009$

0.000

$\mathrm{R}^{2}=0.688$ 


\section{Figure 1: Information shares: estimates and standard errors.}

The estimated information shares represent averages of two alternative orderings $\mathrm{FX} \rightarrow$ home $\rightarrow \mathrm{US}$ and $\mathrm{FX} \rightarrow \mathrm{US} \rightarrow$ home. The values in parentheses are the standard errors of these averaged information shares. The standard errors are obtained by applying the procedure for bootstrapping cointegrating relations suggested by $\mathrm{Li}$ and Maddala (1997). We conduct 1000 bootstrap replications. In each replication the VECM is estimated and the $\psi(1)$ Matrix computed. In each replication the pairs of information share vectors resulting from the orderings $\mathrm{FX} \rightarrow$ home $\rightarrow \mathrm{US}$ and $\mathrm{FX} \rightarrow \mathrm{US} \rightarrow$ home are averaged. The standard errors are obtained by computing the sample standard deviation (based on the sample of 1000 bootstrap replications) of the averaged information shares.

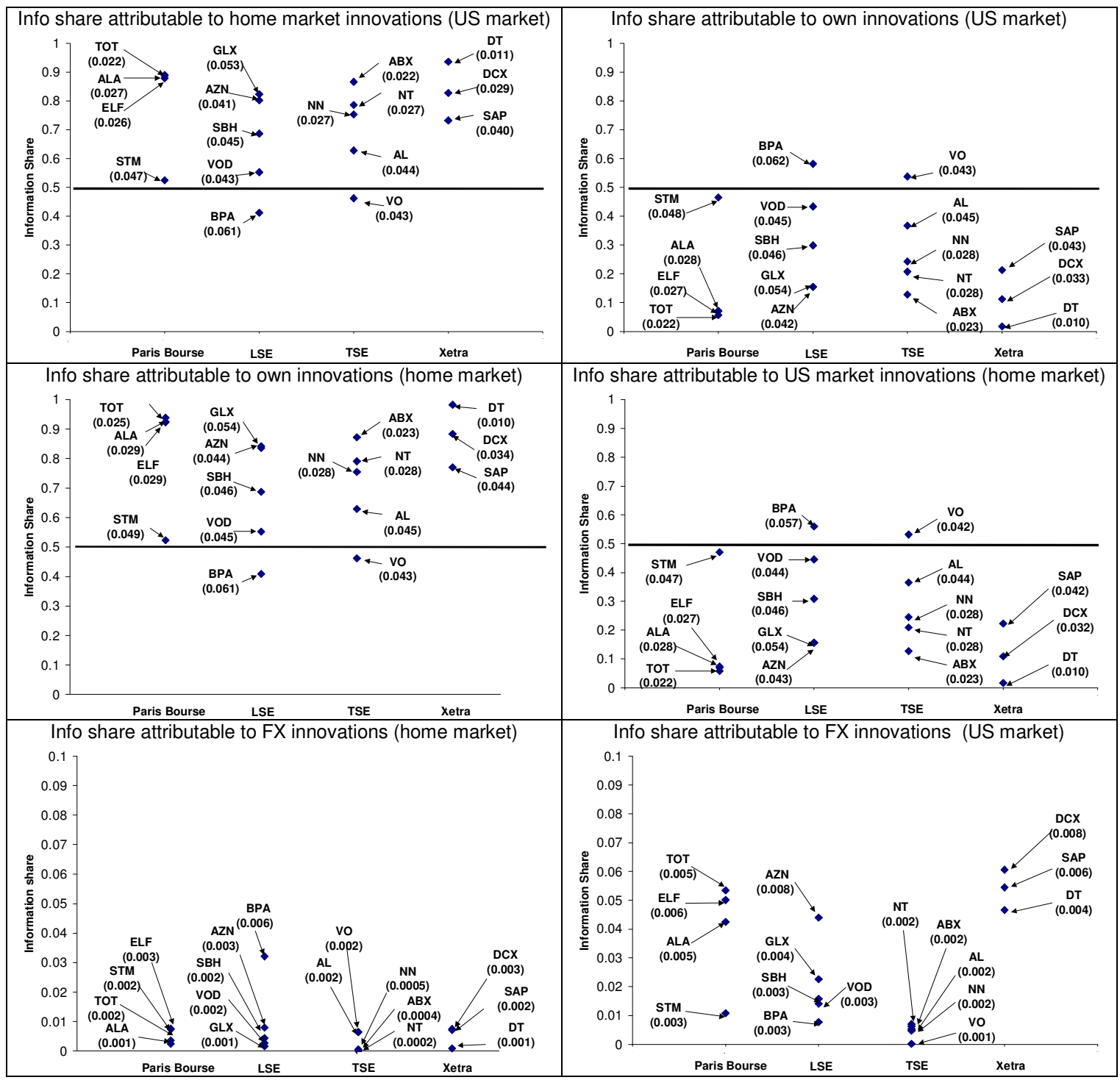

